\title{
Hate Crimes in Poland - Legal and Criminological Perspective
}

\author{
Joanna Narodowska* \\ Maciej Duda* \\ DOI: https://doi.org/10.24040/sap.2021.8.2-3.147-159
}

\begin{abstract}
NARODOWSKA, Joanna - DUDA, Maciej: Hate crimes in Poland - Legal and Criminological Perspective. The aim of the study is to discuss the principles of criminal liability for hate crimes penalized under the Polish Penal Code and to present the criminological aspects of this phenomenon in Poland. In the first (legal) part, three crimes of extremist nature are characterized and Polish solutions in this regard are compared with the provisions of the Slovak Penal Code. In addition, the most important conclusions from the statistical analysis of the Ministry of Justice data for the years 2008-2017 are presented. In the second part (criminological) the authors indicated the reasons of committing hate crimes. Furthermore a description of the phenomenon based on data provided by the National Police Headquarters and the National Public Prosecutor's Office was presented, as well as possibilities of counteracting extremist crime were discussed.
\end{abstract}

\section{Keywords}

Hate crimes, extremism, criminal liability, causes, manifestations, counteraction

\section{Introduction}

One of the social pathologies that has appeared in Poland at the turn of the 20th and 21 st century were hate crimes. This term is used for acts motivated by discriminatory reasons. These crimes are a reflection of problems and conflicts occurring in the society. So far, quite homogeneous Polish society, as a result of migration phenomena, is becoming more and more heterogeneous, multicultural. This generates acts against individuals and groups who differ from the majority community in terms of race, nationality, ethnic origin or religion. In addition, extremist views such as racism, chauvinism, xeno-

\footnotetext{
Joanna Narodowska, PhD. Assistant Professor at the Department of Criminology and Forensic Science, Faculty of Law and Administration, University of Warmia and Mazury in Olsztyn, Poland. Member of the European Society of Criminology, the Polish Society of Criminology and the Green Criminology Working Group. Expert of the International Union for Conservation of Nature and the European Crime Prevention Network. ORCID: https://orcid.org/0000-00031154-5041, mail: joanna.narodowska@uwm.edu.pl

* Maciej Duda, PhD. Assistant Professor at the Department of Criminology and Forensic Science, Faculty of Law and Administration, University of Warmia and Mazury in Olsztyn, Poland. Member of the European Society of Criminology and the Polish Society of Criminology. Expert of the International Union for Conservation of Nature and the European Crime Prevention Network. ORCID: https://orcid.org/0000-0002-8206-3819, mail: maciej.duda@uwm.edu.pl
} 
phobia and anti-Semitism are also publicly promoted and praised. In reality, however, hate crimes are often motivated by economic issues (jobs, state benefits).

Hate crimes are directed against the inherent dignity of the human beings, which is the source of their and freedoms. The Polish Constitution in Article 31 paragraph 2 indicates that "everyone is obliged to respect the freedoms and rights of others". Furthermore, Article 32 paragraph 2 states that "no one shall be discriminated against in political, social or economic life for any reason whatsoever". On the other hand, Article 13, prohibits totalitarian organizations (Nazi, fascist, communist) and organizations permitting racial and national hatred. The consequence of the above mentioned provisions of the Constitution and international conventions ratified by Poland is the criminalization of hate crimes in the Penal Code.

The aim of this study is to present legal and criminological aspects of the phenomenon of hate crimes in Poland. Firstly, the principles and scope of criminal liability for extremist crimes in Polish criminal law will be presented. Then the authors of the paper discusses the causes of this type of crime (etiology), its symptomatic forms (phenomenology) and the possibilities of prevention (prevention).

The subject matter is examined based on such research methods as: literature analysis, dogmatic analysis of Penal Code regulations, comparative analysis of Polish and Slovak regulations and analysis of crime statistics (police, prosecution, judicial).

\section{Legal aspects}

Polish Penal Code was adopted on 6 June 1997 and entered into force on 1 September 1998 after a one year of vacatio legis. ${ }^{2}$ Above Act penalizes crimes motivated by extremist, and radical attitude. In Poland, the term "hate crime" is used to describe such pathological behaviours, however there is no legal definition of them in any Polish legal act. ${ }^{3}$ In the literature on the subject, hate crimes are generally considered to be crimes under Article 119, 256 and 257 of the Penal Code. They are contained in the chapter entitled "Crimes against peace, humanity and war crimes". (Article 119 of the Penal Code) and "Crimes against public order" (Articles 256 and 257 of the Penal Code). These provisions protect both individuals, entire social groups as well as the democratic order of the state and the peaceful coexistence of society.

The crime consisted in Article 119 of the Penal Code provides for criminal liability for using violence or unlawful threat against a group of persons or individuals because of their national, ethnic, racial, political, religious affiliation or because of their irreligiousness. Such act is punishable by imprisonment from 3 months to 5 years.

The crime under Article 256 of the Penal Code provides for criminal liability for three types of prohibited behaviours. The first is propagation of a fascist or other

1 Act of 2 April 1997 Constitution of Republic of Poland (Journal of Laws 1997, No. 78, item 483, consolidated text with amendments).

2 Act of 6 June 1997 Penal Code (Journal of Laws 2020, item 1444, consolidated text with amendments).

3 In the law and criminological literature of the Czech Republic and the Slovak Republic, the equivalent of the concept of "hate crimes" is the concept of "extremism". HERCZEG, J. Trestné činy z nenávisti. Praha : Wolters Kluwer 2007, pp. 10-11; GŘIVNA, T. - SCHEINHOST, M. ZOUBKOWA, I. a kol. Kriminologie. Praha : Wolters Kluwer 2014, pp. 354-373. 
totalitarian state system. The second is incitement to hatred because of national, ethnic, racial or religious differences or irreligiousness. The third one refers to producing, recording, importing, purchasing, storing, possessing, presenting, transporting or sending of prints, recordings or other objects containing content specified in the previous two types of acts (propagation of a totalitarian regime, incitement to hatred). This act is punishable by a fine, restriction of liberty or imprisonment for up to 2 years. Furthermore, if a person is convicted for the offence of possessing extremist materials, the court will order forfeiture of these objects. It is also worth noting that the Penal Code allows for an exception to the above rule. Extremist materials may be possessed in the course of artistic, educational, collecting or scientific activity.

The offence under Article 257 of the Penal Code provides for criminal liability for two types of prohibited behaviours. The first is insulting a group of people or an individual person because of their national, ethnic, racial or religious affiliation or because of their irreligiousness. The second is infringement of physical integrity of another person for the same reasons. Such acts are punishable by imprisonment for up to 3 years.

The above acts can be regarded as hate crimes sensu stricto, as extremist motivation is explicitly featured in the constitutive elements of these crimes. In the literature it is indicated that one can also distinguish hate crimes sensu largo. All criminal offences can be considered as such if they are committed for discriminatory reasons. Such motivation may occur in the case of e.g. murder (Article 148 of the Penal Code), causing injury to health (Article 156 and 157 of the Penal Code), fight or beating (Article 158 of the Penal Code), theft (Article 279 of the Penal Code), robbery (Article 280 of the Penal Code) or destruction of property (Article 288 of the Penal Code). ${ }^{4}$

Similar penalization to Polish regulations can also be found in $\S \S 421,422,422 \mathrm{a}$, 422b, 422c, 422d, 423, 424 and 424a of the Slovak Penal Code of 5 May 2005. Slovak legislation protects the same minority groups as Polish legislation. The penalties for extremist acts under Slovak criminal law are also similarly severe to those in Poland.

An interesting solution of the Slovak Penal Code, however, is the assumption in $\S 140$ that committing a criminal act for extremist reasons is a motivation deserving special condemnation. The Slovak legislator has also defined extremist crimes expressis verbis in $\S 140 \mathrm{a}$. Moreover, in $\S 422 \mathrm{a}, 422 \mathrm{~b} 423,424$ and 424a, provide for more severe criminal liability for an offence committed by a member of an extremist group or a public official. ${ }^{6}$ There are no similar solutions in the Polish criminal law and de lege ferenda consideration should be given to introducing such provisions into the Polish law.

Table no. 1 and chart no. 1 present the number of convictions for hate crimes in Poland between 2008 and 2017. Since 2018, both the National Prosecutor's Office and the Ministry of Justice have stopped publishing data on hate crimes, therefore the subject of analysis covered only last 10 available years. As the data indicate, the num-

4 Destruction of property for extremist reasons in the light of S. Cohen's criminological classification can be classified as the so-called ideological vandalism. COHEN, S. Hooligans, vandals and the community. A study of social reaction to juvenile delinquency. London : University of London 1969, pp. 215.

5 Law no. 300 from 2005 Panal Code (Zákon č. 300/2005 Z.z. Trestný zákon v znení neskorších predpisov).

6 SMIEŠKO, I. Internet a trestné činy extrémizmu. Plzeň : Aleš Čeněk 2017, pp. 66-82. 
ber of hate crimes committed in Poland is not high (30-300 per year) but increasing dynamics of the phenomenon should be of concern.

Table no. 1. Convictions for hate crimes in Poland between 2008 and 2017.

\begin{tabular}{|l|l|l|l|l|}
\hline Year & Article 119 & Article 256 & Article 257 & Total \\
\hline 2008 & 3 & 16 & 17 & 36 \\
\hline 2009 & 19 & 19 & 22 & 60 \\
\hline 2010 & 10 & 9 & 21 & 40 \\
\hline 2011 & 4 & 10 & 19 & 33 \\
\hline 2012 & 10 & 24 & 28 & 62 \\
\hline 2013 & 8 & 29 & 32 & 69 \\
\hline 2014 & 59 & 37 & 65 & 161 \\
\hline 2015 & 67 & 38 & 123 & 228 \\
\hline 2016 & 74 & 83 & 127 & 284 \\
\hline 2017 & 122 & 51 & 104 & 277 \\
\hline Total & $\mathbf{3 7 6}$ & $\mathbf{3 1 6}$ & $\mathbf{5 5 8}$ & $\mathbf{1 2 5 0}$ \\
\hline
\end{tabular}

Source: Own study based on the Ministry of Justice data.

Chart no. 1. Dynamics of hate crimes in Poland in 2008-2017.

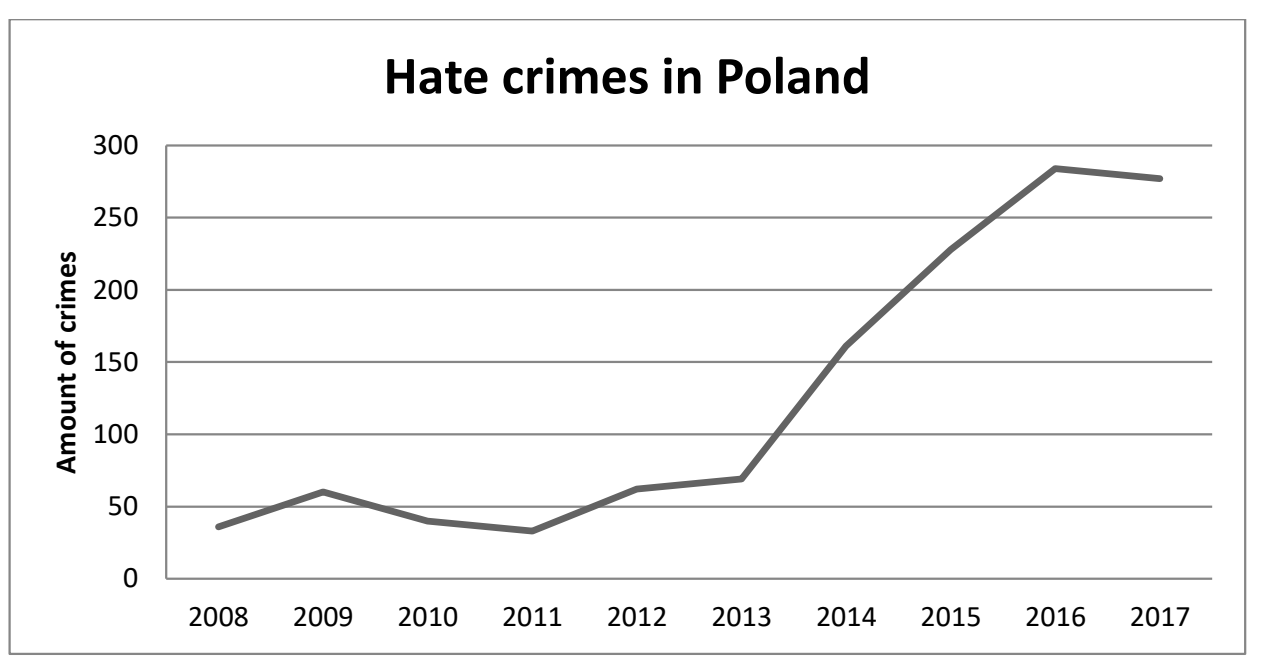

Source: Own study based on the Ministry of Justice data.

Table no. 2 presents the percentage of hate crimes in relation to the total number of crimes in Poland between 2008 and 2017. As the data show, hate crimes constituted an average of about $0.03 \%$ of all crimes in Poland during the studied period. This figure is lower than in the Czech Republic (0.07) and the Slovak Republic (0.10) . ${ }^{7}$

7 VYROSTKO, M. Právne nástroje eliminovania extrémizmu v Českej republike. In Štát a právo 2021, no. 1, DOI: https://doi.org/10.24040/sap.2021.8.1.68-81, pp. 68-81. 
Table no. 2. Percentage of hate crimes among all crimes in Poland between 2008 and 2017.

\begin{tabular}{|l|l|l|l|}
\hline Year & $\begin{array}{l}\text { Total number of } \\
\text { crimes in Poland }\end{array}$ & $\begin{array}{l}\text { Number of hate } \\
\text { crimes }\end{array}$ & $\begin{array}{l}\text { Percentage of hate } \\
\text { crimes }\end{array}$ \\
\hline 2008 & 445204 & 36 & $0,01 \%$ \\
\hline 2009 & 438218 & 60 & $0,01 \%$ \\
\hline 2010 & 459102 & 40 & $0,01 \%$ \\
\hline 2011 & 452543 & 33 & $0,01 \%$ \\
\hline 2012 & 439792 & 62 & $0,01 \%$ \\
\hline 2013 & 383755 & 69 & $0,02 \%$ \\
\hline 2014 & 322174 & 161 & $0,05 \%$ \\
\hline 2015 & 285511 & 228 & $0,08 \%$ \\
\hline 2016 & 321342 & 284 & $0,09 \%$ \\
\hline 2017 & 269197 & 277 & $0,10 \%$ \\
\hline Total & $\mathbf{3 . 8 1 6 . 8 3 8}$ & $\mathbf{1 2 5 0}$ & $\mathbf{0 , 0 3 \%}$ \\
\hline Sour & OW & & \\
\hline
\end{tabular}

Source: Own study based on the Ministry of Justice data.

Table no. 3 shows the detectability of perpetrators of hate crimes in Poland between 2008 and 2017. The detection rate in the studied period was $21 \%$ on average. This is one of the least detected types of crime in Poland. For comparison, the overall detection of crimes in Poland during the researched period was $67 \%$.

Table no. 3. Detectability of perpetrators of hate crimes in Poland in 2008-2017.

\begin{tabular}{|l|l|l|}
\hline Year & Detection of hate crimes & Overall detectability of crime in Poland \\
\hline 2008 & $27 \%$ & $66 \%$ \\
\hline 2009 & $18 \%$ & $67 \%$ \\
\hline 2010 & $21 \%$ & $68 \%$ \\
\hline 2011 & $17 \%$ & $69 \%$ \\
\hline 2012 & $26 \%$ & $68 \%$ \\
\hline 2013 & $19 \%$ & $67 \%$ \\
\hline 2014 & $19 \%$ & $65 \%$ \\
\hline 2015 & $21 \%$ & $65 \%$ \\
\hline 2016 & $24 \%$ & $66 \%$ \\
\hline 2017 & $22 \%$ & $72 \%$ \\
\hline Average & $\mathbf{2 1 \%}$ & $\mathbf{6 7 \%}$ \\
\hline
\end{tabular}

Source: Own study based on the Ministry of Justice data. 
Table no. 4 presents the distribution of punishments sentenced for hate crimes in Poland between 2008 and 2017. As the data show, Polish courts for hate crimes most often apply non-custodial punishments (fine, restriction of liberty, suspended imprisonment). Relatively often, criminal proceedings are also conditionally suspended. The least frequently used are penal measures and the mixed penalty (imprisonment and restriction of liberty) introduced into the Polish penal law in 2015. Absolute imprisonment for hate crimes was sentenced in only $5 \%$ of cases, so it was an ultima ratio punishment.

Table no. 4. Penalties adjudicated for hate crimes in Poland between 2008 and 2017.

\begin{tabular}{|l|l|l|l|l|}
\hline Punishment & Article 119 & Article 256 & Article 257 & Total \\
\hline Absolute imprisonment & 36 & 5 & 21 & 62 \\
\hline Suspended imprisonment & 232 & 58 & 171 & 461 \\
\hline Mixed penalty & 17 & 0 & 1 & 18 \\
\hline Restriction of liberty & 47 & 81 & 101 & 229 \\
\hline Fine & 32 & 102 & 115 & 249 \\
\hline Penal measures & 0 & 2 & 1 & 3 \\
\hline Conditional suspension of proceeding & 12 & 68 & 148 & 228 \\
\hline Total & $\mathbf{3 7 6}$ & $\mathbf{3 1 6}$ & $\mathbf{5 5 8}$ & 1250 \\
\hline
\end{tabular}

Source: Own study based on the Ministry of Justice data.

\section{Criminological aspects}

In Poland, criminologists have paid attention to the phenomenon of hate crimes at the beginning of the 21 st century. This issue has been subject to monographic criminological analysis and is considered in the latest handbooks of criminology. ${ }^{8}$ The problems of hate crimes are part of the so-called cultural criminology. ${ }^{9}$

The origins of such crimes stem from extremist views, stereotypes, prejudice, intolerance, discrimination, stigmatisation and the desire to exclude persons belonging to minorities from society. These crimes are directed against people who are discriminated due to their race, national or ethnic origin, religion or belief, political opinion, gender, sexual orientation, gender identity, disability or any other characteristic that distinguishes them from the rest of society.

Searching for the causes of this type of crime one can refer to such criminological theories as: psychology of crowds (G. Le Bon), social learning (A. Bandura), aggressive behaviour (Z. Freud, K. Lorenz, J. Dollard, N.A. Miller, L. Berkowitz, E. Fromm), anomie (E. Durkheim, R.K. Merton), differential association (E. Sutherland), subcultures (F.W. Thrasher, W.B. Miller, A.K. Cohen, R.A. Cloward, L.E. Ohlin, D. Matza,

8 JURGIELEWICZ-DELEGACZ, E. Przestępstwa motywowane nienawiścią. In PŁYWACZEWSKI, E.W. - REDO, S. - GUZIK-MAKARUK, E.M. - LASKOWSKA, K. - FILIPKOWSKI, W. GLIŃSKA, E. - JURGIELEWICZ-DELEGACZ, E. - PERKOWSKA, M. Kryminologia. Stan $i$ perspektywy rozwoju. Warszawa : Wolters Kluwer 2019, pp. 617-666.

9 KLIMEK, L. Kriminológia ako veda vo vnútroštátnom a medzinárodnom rozmere. In Štát a právo 2020, no. 1, DOI: https://doi.org/10.24040/sap.2020.7.1.27-62, pp. 38. 
M.E. Wolfgang, F. Ferracuti), culture conflict (T. Sellin), group conflict (G.B. Vold) or the Chicago Ecological School (R.E. Park, E.W. Burgess, C.R. Shaw, H.D. McKay). ${ }^{10}$

Hate crimes are part of a wider group of crimes known as criminal offences. Some hate crimes are likewise committed in the form of violent crimes. Without a doubt, these crimes are directed against the public order. According to the classification of E. Sutherland, perpetrators of such crimes are persons referred to as "blue collar crime offenders", i.e. poorly educated, with low income, often unemployed, coming from medium and large cities. The perpetrators of hate crimes often come from extremist environments, defined as the so-called hate groups, such as nationalists, skinheads, pseudo football fans. They can be visually identified by their tattoos promoting extremist content (hate symbols). ${ }^{11}$ When committing the act, perpetrators are often under the influence of alcohol or drugs. There are also cases of recidivism for hate crimes.

Table no. 5 presents the gender distribution of the perpetrators of hate crimes in Poland between 2008 and 2017. As indicated by the data, hate crimes demonstrate almost complete masculinization. Among perpetrators of such crimes in the examined period, $94 \%$ are men and only $6 \%$ are women. For comparison, the average distribution of male to female perpetrators in Poland is $85 \%$ to $15 \%$.

Table no. 5. Gender of perpetrators of hate crimes in Poland between 2008 and 2017.

\begin{tabular}{|l|l|l|l|l|l|}
\hline Hate crime & $\begin{array}{l}\text { Total } \\
\text { number of } \\
\text { suspects }\end{array}$ & $\begin{array}{l}\text { Number } \\
\text { of male } \\
\text { suspects }\end{array}$ & $\begin{array}{l}\text { Percentage } \\
\text { of male } \\
\text { suspects }\end{array}$ & $\begin{array}{l}\text { Number } \\
\text { of female } \\
\text { suspects }\end{array}$ & $\begin{array}{l}\text { Percentage } \\
\text { of female } \\
\text { suspects }\end{array}$ \\
\hline Article 119 & 435 & 415 & $95 \%$ & 20 & $5 \%$ \\
\hline Article 256 & 521 & 492 & $94 \%$ & 29 & $6 \%$ \\
\hline Article 257 & 727 & 665 & $91 \%$ & 62 & $9 \%$ \\
\hline Total & 1683 & 1572 & $94 \%$ & 111 & $\mathbf{6 \%}$ \\
\hline
\end{tabular}

Source: Own study based on the General Police Headquarters data.

Table no. 6 presents the age distribution of perpetrators of hate crimes in Poland between 2008 and 2017. As indicated by the data, hate crimes are committed by perpetrators of all age groups. It is only after the age of 50 that criminal activity in this regard clearly decreases. This trend is consistent with the general tendency for crime in Poland. What is noteworthy, at the same time, a large percentage of perpetrators are juveniles. ${ }^{12}$

10 BUBELINI, J., Kriminologické teórie a prevencia kriminality. Bratislava : Ministerstvo vnútra SR 2008. pp. 19-25; HOLCR, K. a kol. Kriminologie. Praha : Leges 2009, pp. 33-41; NOVOTNÝ, O. - ZAPLETAL, J. a kol. Kriminologie. Praha : Wolters Kluwer 2008, pp. 100-107.

11 VEGRICHTOVÁ, B. Symbolika kriminálniho tetováni. Plzeň : Aleš Čeněk 2016, pp. 103-125.

12 In Polish criminal law, a person over the age of 17 is considered to be capable of bearing full criminal liability. 
Table no. 6. Age of perpetrators of hate crimes in Poland between 2008 and 2017.

\begin{tabular}{|l|l|l|l|l|l|l|}
\hline Hate crime & $\begin{array}{l}\mathbf{0 - 1 6} \\
\text { years }\end{array}$ & $\begin{array}{l}\mathbf{1 7 - 2 0} \\
\text { years }\end{array}$ & $\begin{array}{l}\mathbf{2 1 - 2 4} \\
\text { years }\end{array}$ & $\begin{array}{l}\mathbf{2 5 - 2 9} \\
\text { years }\end{array}$ & $\begin{array}{l}\mathbf{3 0 - 4 9} \\
\text { years }\end{array}$ & $\begin{array}{l}\text { Over 50 } \\
\text { years }\end{array}$ \\
\hline Article 119 & $15,10 \%$ & $22,20 \%$ & $13,40 \%$ & $16,80 \%$ & $26,30 \%$ & $6,20 \%$ \\
\hline Article 256 & $18,30 \%$ & $22,60 \%$ & $16,30 \%$ & $15,70 \%$ & $22,10 \%$ & $5,00 \%$ \\
\hline Article 257 & $12,60 \%$ & $13,40 \%$ & $13,20 \%$ & $18,60 \%$ & $32,50 \%$ & $9,70 \%$ \\
\hline Total & $\mathbf{1 5 , 3 3 \%}$ & $\mathbf{1 9 , 4 0 \%}$ & $\mathbf{1 4 , 3 0 \%}$ & $\mathbf{1 7 , 0 3 \%}$ & $\mathbf{2 6 , 9 7 \%}$ & $\mathbf{6 , 9 7 \%}$ \\
\hline
\end{tabular}

Source: Own study based on the General Police Headquarters data.

The modus operandi of perpetrators of hate crimes most often consists in:

- posting extremist content on the Internet,

- using violence against a person,

- using threats against a person,

- posting extremist graffiti on walls, buildings, fences

- displaying extremist banners or raising extremist slogans during demonstrations, gatherings, rallies

- issuing extremist books and press publications

- displaying extremist banners or raising extremist slogans during sports competitions. ${ }^{13}$

In the literature, it is also noted that hate crimes can take the form of: songs, paintings, posters, book publications, comic books, graffiti, symbols, gestures or tattoo. It is also indicated that hate crimes are more and more often committed on the Internet in the form of the so-called hate speech. As a result, some forms of hate crime can be classified as cybercrime ${ }^{14}$ In the forms of physical assaults, these crimes are committed primarily in cities, and especially in public places (public transport, street, park, shop).

According to statistics, the most victims of hate crimes are: Muslims, Ukrainians, Jews, people of black race, Roma, Poles, Catholics, Syrians. In recent years, an interesting trend has been noticed concerning the victims of hate crimes. Just 10-20 years ago, the victims were mostly Roma and Jews. Currently, however, more and more acts of this nature are directed against Muslims, Arabs, people of black race and Ukrainians. This is certainly related to economic migration to Poland. In Poland, there are no hate crimes committed by representatives of ethnic minorities against the majority community. On the other hand, Slovak criminologists point to such a state of affairs in the context of attacks perpetrated by Roma. ${ }^{15}$

In the context of victims of hate crimes, it should be stressed that they are characterised by high victimization because of their visual difference from the rest of society. Moreover, they are particularly vulnerable to secondary victimization as a

13 Prokuratura Krajowa, Sprawozdanie dotyczace spraw o przestepstwa popetnione z pobudek rasistowskich, antysemickich lub ksenofobicznych prowadzonych w 2017 roku w jednostkach organizacyjnych prokuratury, Warszawa 2018.

14 KLIMEK, L. - ZÁHORA, J. - HOLCR, K. Počitačová kriminalita v európskych súvislostiach. Bratislava : Wolters Kluwer 2016, pp. 22-25.

15 ŠIMOVÁ, Z. Obete trestných činov rasovo a etnicky motivovaných. In KOŠECKÁ, D. (ed.). Obete kriminality. Zbornik príspevkov z medzinárodnej konferencje. Bratislava : Paneurópska vysoká škola 2013, pp. 290. 
result of the malfunctioning of law enforcement agencies. On the other hand, relatives and acquaintances of victims are vulnerable to indirect victimization as they usually belong to the same minority group.

In addition, hate crimes are characterized by a high dark figure of crime. The reason of "underreporting" phenomenon, i.e. low reporting of this crime, is inter alia, fear of revenge of the perpetrator or of being victimized again, lack of knowledge of the language, lack of trust in law enforcement agencies, unwillingness to disclose their illegal residence in Poland.

In the case of some hate crimes, it is impossible to identify a direct victim (e.g. incitement to hatred against an entire minority group, placement of racist graffiti), nevertheless it cannot be assumed that hate crimes are the so-called victimless crimes. Furthermore, it should be noted that hate crimes are symbolic. Even if a single person is the victim of a crime, this crime is in fact directed against an entire social group, to which the victim belongs. ${ }^{16}$

Countering hate crime is a particularly important issue in criminal policy, because hate crimes undermine the peaceful coexistence of various social groups. Their escalation can lead to serious collective behaviour violating public order and state security, such as demonstrations, riots, pogroms. The occurrence of these crimes is also used as an argument in political struggle. Moreover, in the context of the increasing phenomenon of migration, in particular of an intercultural nature, it can be expected that the number of hate crimes will increase. Resistance of the autochthonous community against allochthonous groups is in line with the concept of the so-called "clash of civilizations" formulated by S. Huntington. ${ }^{17}$

It should be highlighted, however, that Polish law enforcement agencies are taking active efforts to control this crime. Police officers are trained in courses on how to respond to hate crimes. Criminal proceedings on hate crimes conducted by the prosecutor's office are under the official supervision of higher level prosecutor's offices as particularly important cases, and in each prosecutor's district a prosecutor specializing in such cases is appointed. Combating organized and cross-border forms of extremist crime is also within the competence of the Internal Security Agency. Assistance to victims of hate crimes is provided by numerous non-governmental organizations (NGOs), which also carry out educational campaigns for tolerance. In addition, citizens can report cases of hate crimes noticed on the Internet to the Computer Security Incident Response Team (CSIRT). The 5-year Strategies for Combating Radicalization and Extremism adopted in the Slovak Republic are an instrument to be considered for introduction in Poland. ${ }^{18}$

16 DUDA, M. Przestępstwa z nienawiści jako współczesne wyzwanie dla kryminologii. In PŁYWACZEWSKI, E.W. - JURGIELEWICZ-DELEGACZ, E. - DAJNOWICZ-PIESIECKA, D. (ed.). Współczesna przestępczość i patologie społeczne z perspektywy interdyscyplinarnych badań kryminologicznych. Warszawa : C.H. Beck 2019, pp. 39-48.

17 HUNTINGTON, S.P. The Clash of Civilizations and the Remaking of World Order. New York : Simon \& Schuster 2011, pp. 245.

18 DANIHEL V., Niekol'ko poznámok k prevencii kriminality extrémistov. In KOŠECKÁ, D. (ed.). Obete kriminality. Zbornik príspevkov z medzinárodnej konferencje. Bratislava : Paneurópska vysoká škola 2013, s. 281. 


\section{Conclusion}

Hate crimes are a relatively new criminal phenomenon. In Poland they have appeared at the turn of the 20th and 21 st centuries. In response to this contemporary social pathology, the Polish legislator has penalized behaviour of an extremist nature (radical, discriminatory) in the Penal Code. Articles 119, 256 and 257 of the Polish Penal Code protect individuals or groups distinguished on the basis of their national, ethnic, racial, political, religious or irreligious affiliation. Furthermore, aforementioned provisions, prohibit the propagation of totalitarian regimes. The purpose of the above regulations is to ensure peaceful coexistence of individuals and groups in a democratic, pluralistic society.

A comparative analysis of the provisions of the Penal Code of the Slovak Republic allows for the conclusion that the Polish and Slovak provisions converge as regards both the scope of typification and penalties for this type of crimes. However, the Polish legislator might pay attention to some Slovak solutions. Furthermore, the definition of the concept of extremism, the recognition of extremist motivation as a motivation deserving particular condemnation and the increase in penalties for crimes committed by members of extremist groups or public officials shall be assessed positively.

Between 30 and 300 perpetrators are convicted of hate crimes every year. In recent years, there has been a clear increase in the number of such crimes. However, they still constitute only about $0.1 \%$ of all crimes. The detection of hate crimes is very low and amounts to approximately $20 \%$. Suspended prison sentences, restriction of liberty sentences and fines are mainly adjudicated for these acts. The following penalties are most often imposed for hate crimes: suspended imprisonment, restriction of liberty and a fine.

From a criminological perspective, research on hate crimes focuses on the etiology of the phenomenon, its phenomenology and the possibilities of counteraction. The cause of the occurrence of this type of crimes are extremist views that result in attitudes of discrimination and hostility towards persons belonging to minorities.

Hate crimes can be classified as: criminal offences, offences against public order and violent crimes. The part of hate crimes that is committed on the Internet (about $50 \%$ ) also fits into the concept of cybercrime. The typical perpetrator of hate crimes is a man, aged between 20 and 40 years, a city dweller, poorly educated, unemployed or a manual worker. The most common victims are: Muslims, Ukrainians, Jews, people of black race and Roma. Hate crimes often result in secondary victimization of victims and indirect victimization of their relatives. Despite the frequent lack of direct victimization, hate crimes cannot be considered as victimless crimes because they are directed against entire minority groups and are symbolic in nature.

The services responsible in Poland for counteracting hate crimes are the police, the prosecutor's office and the Internal Security Agency. However, more important than combating manifestations of extremist crimes seems to be forming attitudes of tolerance for differences through appropriate government social policy, the impact of the media, education and the activities of non-governmental organizations. 


\section{Bibliography:}

- Act of 2 April 1997 Constitution of Republic of Poland (Journal of Laws 1997, No. 78, item 483, consolidated text with amendments).

- Act of 6 June 1997 Penal Code (Journal of Laws 2020, item 1444, consolidated text with amendments).

- BUBELINI, J. 2008. Kriminologické teórie a prevencia criminality. Bratislava : Ministerstvo vnútra SR. pp. 19-25.

- COHEN, S. 1969. Hooligans, vandals and the community. A study of social reaction to juvenile delinquency. London: University of London 1969. pp. 215.

- DANIHEL, V. 2013. Niekol'ko poznámok k prevencii kriminality extrémistov. In KOŠECKÁ, D. (ed.). Obete kriminality. Zbornik príspevkov z medzinárodnej konferencie. Bratislava: Paneurópska vysoká škola. ISBN 978-80-8153-015-9. pp. 281.

- DUDA, M. - JURCZAK, J. 2013. Przestępstwa z nienawiści jako element przestępczości stadionowej. Mowa, symbole i gesty nienawiści w świetle badań. In MAZOWIECKA, L. (ed.) Ofiary przestępstw z nienawiści. Warszawa : Wolters Kluwer. ISBN 978-83-264-4205-6. pp. 162-184.

- DUDA, M. 2016. Przestępstwa z nienawiści. Studium prawnokarne i kryminologiczne. Olsztyn : WPiA UWM. ISBN 978-83-62383-73-3. pp. 409.

- DUDA, M. 2017. Przestępstwa z nienawiści jako współczesne wyzwanie dla kryminologii. In PŁYWACZEWSKI, E.W. - JURGIELEWICZ-DELEGACZ, E. - DAJNOWICZ-PIESIECKA, D. (ed.). Wspótczesna przestępczość i patologie spoteczne z perspektywy interdyscyplinarnych badań kryminologicznych. Warszawa : C.H. Beck. ISBN 978-83-255-9006-2. pp. 39-48.

- GŘIVNA, T. - SCHEINHOST, M. - ZOUBKOWA, I. a kol. 2014. Kriminologie. Praha : Wolters Kluwer. ISBN 978-80-7478-614-3. pp. 354-373.

- HERCZEG, J. 2017. Trestné činy z nenávisti. Praha : Wolters Kluwer. ISBN 97880-7357-311-9. pp. 10-11.

- HOLCR, K. a kol. 2009. Kriminologie. Praha : Leges. ISBN 978-80-87212-23-3. pp. 33-41.

- HOŁYST, B. 2003. Nietolerancja jako źródło zachowań przestępczych. In „Prokuratura i Prawo”, no. 11, pp. 7-26.

- HUNTINGTON, S.P. 2011. The Clash of Civilizations and the Remaking of World Order. New York : Simon \& Schuster. ISBN 978-1451-62-897-5. pp. 245.

- JURCZAK, J. - DUDA, M. 2010. Stadion piłkarski jako miejsce ideologicznych manifestacji. In Policja, no. 4, ISSN 1640-9280. pp. 55-61.

- JURGIELEWICZ-DELEGACZ, E. 2019. Przestępstwa motywowane nienawiścią. In PŁYWACZEWSKI, E.W. - REDO, S. - GUZIK-MAKARUK, E.M. LASKOWSKA, K. - FILIPKOWSKI, W. - GLIŃSKA, E. - JURGIELEWICZDELEGACZ, E. - PERKOWSKA, M. Kryminologia. Stan i perspektywy rozwoju. Warszawa : Wolters Kluwer. ISBN 978-83-8160-625-7. pp. 617-666.

- KLIMEK, L. - ZÁHORA, J. - HOLCR, K. 2016. Počitačová kriminalita v európskych súvislostiach. Bratislava: Wolters Kluwer. ISBN 978-80-8168-538-5. pp. 22-25. 
- KLIMEK, L. 2020. Kriminológia ako veda vo vnútroštátnom a medzinárodnom rozmere. In Štát a právo, no. 1, ISSN 1339-7753, DOI: https://doi.org/10.24040/ sap.2020.7.1.27-62, pp. 38.

- KLIMEK, L. a kol. 2020. Kriminológia vo vnútroštátnom a medzinárodnom rozmere. Bratislava : Wolters Kluwer. ISBN 978-80-571-0251-9. pp. 95-101.

- Law no. 300 from 2005 Panal Code (Zákon č. 300/2005 Z.z. Trestný zákon v znení neskorších predpisov).

- NARODOWSKA, J. - DUDA, M. 2018. Legal and criminological aspects of cybercrimes in Poland - selected issues. In Digitalization in Law. Conference papers. 6th International Conference of PhD Students and Young Researchers, Vilnius : Vilnius University. ISBN 978-609-459-986-6. pp. 148-159.

- NARODOWSKA, J. - DUDA, M. 2019. Hate speech in art. What are the limits of artistic freedom?. In PŁYWACZEWSKI, E.W. - GUZIK-MAKARUK, E.M. (ed.). Current Problems of the Penal Law and Criminology/Aktuelle Probleme des Strafrechts und der Kriminologie. Warszawa : C.H Beck. ISBN 978-83-8158-9024. pp. 567-579.

- NARODOWSKA, J. - DUDA, M. 2020. New Forms of Crimes Connected with Cyberspace in Poland: Legal and Criminological Perspective. In BANI, E. RUTKOWSKA-TOMASZEWSKA, E. - PACHUCA-SMULSKA, B. (ed.). Public and Private Law and the Challenges of New Technologies and Digital Markets. Volume 1. Regulatory Challenges. Warszawa: C.H. Beck. ISBN 978-83-8198-0708. pp. 277-293.

- NOVOTNÝ, O. - ZAPLETAL, J. a kol. 2008. Kriminologie. Praha : Wolters Kluwer. ISBN 978-80-7353-376-8. pp. 100-107.

- ŠIMOVÁ, Z. 2013. Obete trestných činov rasovo a etnicky motivovaných. In KOŠECKÁ, D. (ed.). Obete kriminality. Zbornik príspevkov z medzinárodnej konferencje. Bratislava : Paneurópska vysoká škola. ISBN 978-80-8153-015-9. pp. 290.

- SMIEŠKO, I. 2017. Internet a trestné činy extrémizmu. Plzeň : Aleš Čeněk. ISBN 978-80-7380-691-0. pp. 66-82.

- VEGRICHTOVÁ, B. 2016. Symbolika kriminálniho tetováni. Plzeň : Aleš Čeněk. ISBN 978-80-7380-579-1. pp. 103-125.

- VYROSTKO, M. 2021. Právne nástroje eliminovania extrémizmu v Českej republike. In Štát a právo, no. 1, ISSN 1339-7753, DOI: https://doi.org/10.24040/ sap.2021.8.1.68-81, pp. 68-81.

\section{Summary: Hate Crimes in Poland - Legal and Criminological Perspective}

The aim of the study is to present the phenomenon of hate crimes from a legal and criminological perspective. In Poland, the basis of criminal liability for hate crimes are the provisions of Articles 119, 256 and 257 of the Penal Code. They are formulated similarly to the provisions of $\S 421-424$ a of the Slovak Penal Code. The same social groups are protected and similar penalties are provided for the offences. Hate crimes constitute approximately $0.1 \%$ of all crimes in Poland. Each year, between 30 and 300 perpetrators are sentenced for hate crimes. However, the increasing dynamics of such crimes is worrisome. The perpetrators of hate crimes are mainly young, uneducated 
men from the city, with social problems. The most vulnerable to becoming a victim are immigrants: Muslims, Ukrainians, Jews, people of black race and Roma. These crimes are committed in the form of violent crimes or hate speech. I has been observed that more and more crimes of this kind are committed in cyberspace (about 50\%). These crimes cannot in any case be marginalized as they represent a significant threat to public order in the country.

Dr Joanna Narodowska Assistant Professor University of Warmia and Mazury in Olsztyn Faculty of Law and Administration Department of Criminology and Forensic Science ul. K. Obitza 1 10-725 Olsztyn Poland joanna.narodowska@uwm.edu.pl

Dr Maciej Duda Assistant Professor University of Warmia and Mazury in Olsztyn Faculty of Law and Administration Department of Criminology and Forensic Science ul. K. Obitza 1 10-725 Olsztyn Poland maciej.duda@uwm.edu.pl 